\title{
9 \\ Indigenous Women, Marriage and Colonial Mobility
}

\section{Angela Wanhalla}

Imperial events, transport routes and communication networks created out of exploration, trade and colonisation opened up new possibilities for global Indigenous mobility during the eighteenth and nineteenth centuries. ${ }^{1}$ In recent decades, patterns of Indigenous mobility across these imperial routes and pathways have begun to be traced in an effort to challenge the assumption that 'networks are associated only with colonisers' and that 'indigenous societies are exclusively local'. ${ }^{2}$ As the editors of a special issue of American Quarterly on alternative contact histories argued, to interpret Indigenous peoples as invested only in concerns of their lands' ignores instances of 'Indigenous peoples in the role of active, mobile, and even cosmopolitan actors on the world stage' that 'complicate static or incomplete definitions of Indigenous identity'. ${ }^{3}$

1 My thanks to Sherry Farrell Racette and Krista Barclay, as well as Frank Tough and his research team at the Métis Archival Project at the University of Alberta, for sharing their knowledge of fur trade families and métis history with me, and for sourcing archival material for this article. I am also grateful to Sarah Carter and Adele Perry for enabling my visit to the University of Alberta and the University of Manitoba as a Distinguished Visitor at both universities in early 2015, which allowed me to conduct research on the Grieve and Harrold families at local archives. I would like to particularly acknowledge participants at the Indigenous Mobilities workshop for their critical feedback on a draft version of this chapter, and Rachel Standfield for her thoughtful and considered advice. Finally, I gratefully acknowledge the support of a Royal Society of New Zealand Rutherford Discovery Fellowship, which supported the research for this chapter. Paterson 2013; Burton 2012.

2 Lester 2014: 2.

3 Lai and Smith 2010: 408, 409. 
In this scholarship though, Indigenous women's mobility within and across imperial and colonial spaces is not as coherently described or examined as that of Indigenous men who are firmly located in intellectual, religious, political, trade and print culture networks. ${ }^{4}$ As chapters in this volume indicate, Indigenous men's motivations and experiences of global travel are increasingly gaining scholarly attention; however, Indigenous women's mobility is rarely recognised. ${ }^{5}$ Although some recent work has demonstrated that Indigenous women were involved in networks of Indigenous activism, were writers and critics of imperialism and colonialism, authored petitions and engaged in humanitarian debates, ${ }^{6}$ scholars have yet to fully explore Indigenous women's participation in imperial networks or elaborate the variety of ways in which they were active mobile subjects.

As historical subjects, Indigenous women tend to be associated with forms of involuntary movement; their mobility across imperial and colonial space is often equated with violence, coercion and abandonment. A well-known example from early New Zealand is Atahoe (1790-1810), the daughter of Ngāpuhi chief Te Pahi, who accompanied her English husband, the ex-convict George Bruce, to Malacca, was then kidnapped and taken to Calcutta, before eventually being abandoned by Bruce in Sydney, where she died. ${ }^{7}$ In Hawai $i$, Indigenous women were among the earliest travellers to the Pacific Northwest Coast of modern-day Oregon, Washington state and British Columbia, sometimes by choice, but more often facilitated by engagement in domestic service for European families or, under duress, as captives. ${ }^{8}$ The link between involuntary mobility and Indigenous women's labour is also prevalent in relation to their involvement in early colonial maritime resource economies, especially sealing. ${ }^{9}$ In an important intervention into this history, Lynette Russell queried whether the method of their mobility — that is, whether they 'were captured or traded, were forced or voluntarily arrived at their location'should 'be the framework through which we see the rest of their lives?' 10 Russell's chapter in this volume applies this conceptual approach to

4 For instance, O’Brien 2014; Warrior 2005; Carey and Lydon 2014; Lester 2014; Laidlaw 2014; Elbourne 2005.

5 O'Malley 2015; Weaver 2014.

6 For instance, Banivanua Mar 2013; Hoxie 2014.

7 Legge 1991. See also, O’Brien 2006; Banivanua Mar 2015.

8 Barman and McIntyre Watson 2006.

9 Russell 2012.

10 Russell 2012: 18. 
analyse Aboriginal Tasmanian women's travel in the nineteenth century. In this chapter, I utilise the 'life geographies ${ }^{11}$ of two women whose paths crossed momentarily in southern New Zealand to argue that marriage and kinship networks are an important, but overlooked, pathway to track the specificities of Indigenous women's mobility. Agnes Grieve (1830-1903), of Swampy Cree ancestry, was born in Canada, and her travel across vast distances followed imperial pathways, bringing her to New Zealand in 1848. Agnes lived near Jane Palmer (1830-98), whose localised pattern of seasonal mobility was enabled by Indigenous geographies and kinship networks. These women's lives overlapped between 1849 and 1861 when, during that period, they shared space in colonial Otago, where their respective kinship networks energised their ties to place.

Agnes Grieve and Jane Palmer lived near each other at the small river settlements of Taieri Ferry and Maitapapa. Both villages are on the Taieri Plain, which is dominated by a tidal river that was a main communication and transport route for colonists and travellers, carrying them, their goods and stock inland from the coastal port of Taieri Mouth on a route that took them through a narrow gorge before opening out onto the plain itself. Here, travellers disembarked at the settlement of Taieri Ferry, where Agnes Grieve managed an accommodation house on the tribal lands of local Käi Tahu, directly across the river from the Indigenous people who had been dispossessed, including my three-times great-grandmother, Jane Palmer. In this region, waterways were an essential conduit of people and goods, connecting inland regions to the coast and the sea. More importantly, the river, inland lakes and wetlands were compelling sites of coexisting, overlapping and, at times, competing colonial and Indigenous geographies and kinship networks.

Indigenous women participated in imperial networks; however, the unevenness of the archival record limits the possibility of making any broad assessment of the patterns of their mobility or its scale. Agnes Grieve and Jane Palmer, like many Indigenous women, left a light imprint on the textual archive. Neither woman left behind a cache of letters or correspondence and Agnes has no direct descendants in New Zealand to maintain her memory. Yet, a paucity of documentary material is not necessarily an impediment to reconstituting subaltern or Indigenous lives, as Clare Anderson and Adele Perry's work has demonstrated. ${ }^{12}$ Instead,

11 Daniels and Nash 2004: 450.

12 Anderson 2012; Perry 2015. See also Ballantyne 2012: 105-22; Anderson 2011. 
as contended by Turtle Mountain Chippewa scholar Danika MedakSaltzman, a wider array of sources ought to be utilised to illustrate the 'many ways that Indigenous peoples have always been active actors on the global stage'; to 'do otherwise would be to perpetuate historical silences'. ${ }^{13}$ Medak-Saltzman examined encounters between Indigenous women at the 1904 St Louis Exposition as depicted in photographs, focusing on how such:

Moments of colonial celebrations of empire may have inadvertently served anticolonial purposes by presenting the Indigenous participants with opportunities to interact across larger distances than had been practical or possible in the past. ${ }^{14}$

According to Medak-Saltzman, to relate Indigenous-Indigenous moments of contact and engagement at international exhibitions and world's fairs solely within an analytical framework of imperial ethnographic display practices was a 'rationale for leaving questions about Native experiences unexamined'. ${ }^{15}$ Opening her mind to alternative interpretations that arise from photographs of two Indigenous women conversing with each other outside the exhibition space, she argued that such photographs were evidence of Indigenous experiences on the world's stage that had been sidelined in favour of the more abundant visual source material that depicted Indigenous people on display. This alternative visual evidence of Indigenous-Indigenous encounter serves as a reminder that imperial and colonial exhibitions were forums through which Indigenous peoples could connect with each other and create spaces for themselves.

While noting the increased attention paid to uncovering modes of Indigenous participation in imperial networks in the context of settler colonialism and dispossession in recent decades, Alan Lester and Zoe Laidlaw have pointed out that 'where and how Indigenous people connect with trans-global networks [remains] ill-defined'. ${ }^{16}$ One important pathway yet to be integrated into the analysis of imperial networks and mobility is intermarriage: a social, political and economic practice utilised by Indigenous peoples in many colonial contexts to manage the impacts of contact and colonisation. In this chapter, I depart from the standard view of intermarriage as a process deployed by Indigenous communities

13 Medak-Saltzman 2010: 592-93.

14 Medak-Saltzman 2010: 593.

15 Medak-Saltzman 2010: 593.

16 Lester and Laidlaw 2015: 7. 
to tie an outsider, usually a white man, to a particular place and family, towards an interpretation that regards intermarriage as one pathway for the global mobility of Indigenous and mixed-descent women. Through intermarriage, as the lives of Agnes and Jane reveal, Indigenous women's lives intersected with the processes of global economic expansion and settler colonialism in ways that were different from the experience of their male relatives. To map the terrain of Agnes' and Jane's mobility through their marriage and kinship networks, I draw upon archival fragments from several colonial sites (Canada, the Orkney Islands and New Zealand) produced by several bodies (the Hudson's Bay Company, colonial provincial governments and the colonial state) that inadvertently reveal Indigenous women's circulation across and within colonial spaces. ${ }^{17}$

\section{Life Geographies and Kinship Networks}

Imperial and colonial pathways of mobility enacted through the fur trade relied upon technologies and infrastructure, such as global communication and transport networks. ${ }^{18}$ Agnes was born into a Cree world that coexisted and engaged with an expanding fur-trade economy and infrastructure in western Canada that drew upon a mobile population of employees. The land-based fur trade grew up around posts and stations located near lakes and rivers, which were vitally important for conveying goods, pelts and letters across country; it founded its success, in part, upon the processing skills of Indigenous women, many of whom were drawn into the trade through marriage. ${ }^{19}$

While the trade had a significant impact upon Indigenous societies in western Canada, tying places and peoples together through capital and kinship connections, it also created work for the largely impoverished male population of the Orkney Islands, near the Scottish mainland. Agnes' father, James Grieve, was one of these Orcadians. He entered into a five-year contract with the Hudson's Bay Company (HBC) at Stromness on 1 June 1816, aged 19. Like many Orcadians in the trade, Grieve joined up at a time when the company was expanding both territorially

17 On the convergence of local and global mobility, settler colonialism and indigeneity, see Lester and Laidlaw 2015: 1-23.

18 See Ballantyne 2011.

19 Van Kirk 1980: 4. On mobility in Métis culture and history, see St-Onge, Podruchny and Macdougall 2012. 
and in terms of labour requirements. ${ }^{20}$ Orkneymen sought employment with the HBC, as they had few other options - outside of the merchant navy or northern whaling expeditions to Greenland and the Davis Strait. A contract with the company promised stable employment, far better wages than they could get elsewhere and the chance to accrue some savings. Noted for their fishing and boatbuilding skills, as well as their reputation for reliability, Orcadians were sought by the $\mathrm{HBC}$ too, leading them to dominate the western Canadian fur trade. By the last decade of the eighteenth century, 416 out of 530 overseas HBC servants-a category that included labourers, canoemen, fishermen, carpenters, boat builders, sailors, blacksmiths and tailors-were from the Orkney Islands. ${ }^{21}$

Fur-trade employees were peripatetic. Grieve, for instance, was employed in the northern department at York Factory, the first HBC trading post, which was regarded as company headquarters. He also worked as a bowsman at Island Lake, but spent the majority of his life, from 1824 until his death in 1876, at Oxford House in northern Manitoba. ${ }^{22}$ Initial contracts with the company were for five years, and many men served their time and returned to the islands with their savings. Others, like James Grieve, lived out their life in Canada, especially after establishing kinship ties in the country. Marriage to an Indigenous woman, whether by the 'custom of the country' or Christian rite, increased the likelihood of a trader settling in the region; this was the case with Grieve, who married a Swampy Cree woman, known in HBC records as 'Mary'. James and Mary had six children: John, James, Thomas, William, George and Agnes. ${ }^{23}$ Agnes' future husband, James Harrold, hailed from Rousay, in the northern Orkney Islands; he signed up as a labourer for the HBC in 1836. ${ }^{24}$ Harrold initially worked in the Mackenzie River District, but, by the early 1840s, was at York Factory. He probably encountered Agnes while employed as a labourer and fisherman at Island Lake, near Oxford

20 Van Kirk 1980: 21. For further discussion of the predominance of Orkney Islanders in the Canadian fur trade, see Burley 1997.

21 Van Kirk 1980: 4; Burley 1997: 66-71; Stephen 2006: 6, 30.

22 Beaumont 1984: 2. For a Cree perspective, see Beardy and Coutts 1996. Oxford House was established as an HBC fur-trading post in 1798. Today, it is the home of a First Nations Cree community. Located near the mouth of Hayes River, Oxford House is situated on the fur-trade route between Norway House, to the south, and York Factory, to the north. Traders used Hayes River to move between these sites.

23 Whyte 1995: 114.

24 Transcript of Census Returns-Rousay, Egilsay and Wyre 1841, Orkney Library and Archive, Orkney Islands. 
House. They married at York Factory on 16 September $1847 .{ }^{25}$ Agnes was 16 years old. Barely a week later, the newly married couple took passage on the HBC ship Prince Rupert for London, and then to the Orkney Islands. ${ }^{26}$

Fur traders utilised the HBC's global transportation routes to enable the mobility of their families. For instance, it was not uncommon for children of fur traders and Indigenous women to be sent to the Orkney Islands for schooling, although this opportunity was largely restricted to the sons of men from the upper echelon of fur-trade society. ${ }^{27}$ Children born to men of means and some wealth may have gained access to an education, and lived transcolonial lives, but their mothers rarely journeyed to the birthplace of their fur-trader partner. ${ }^{28}$ There is evidence that some women moved to Britain with their husbands in the post-1821 era, when the HBC's London Committee 'lifted its ban on employees taking their native wives to Britain provided they had adequate means to support their families'. ${ }^{29}$ However, as Sylvia Van Kirk noted, this was a rare event; in the cases she cited, it was limited to the officer class who had the means, connections and opportunity to do so. ${ }^{30}$ Agnes and James married at a time when fur-trade marriage patterns were undergoing a transition; as the $\mathrm{HBC}$ expanded and employed greater numbers of men, intermarriage expanded beyond the confines of the officer class to servants and labourers, giving them access to rights and privileges previously enjoyed by officers alone. ${ }^{31}$ As intermarriage became more common within all ranks of the company, a hierarchy of marriage partners emerged that correlated with the HBC rankings; officers were encouraged to marry European women, while those of medium rank were encouraged to marry women of mixed ancestry. ${ }^{32}$ In this way, marriage facilitated opportunities for mobility: it registered social and economic mobility within fur-trade society and, for some, such as Agnes, generated the opportunity for international travel.

25 Whyte 1995: 120. Grieve Family Search File, Hudson's Bay Company Archives (HBCA), Archives of Manitoba, Winnipeg. The couple 'were married according to form of the Church of England' by the chief trader. Extracts from York Factory Journal, Autumn 1847, B.239/a/167, HBCA, Archives of Manitoba, Winnipeg.

26 Marriage certificate, York Factory Marriage Certificates and certified promises of marriage, 1829-1853, HBCA, Archives of Manitoba, Winnipeg. Ships' Logs 1847.

27 Van Kirk 1980: 83.

28 Van Kirk 1980: 45. On the transcolonial lives of some of these mixed-race children, see Morgan 2014; McCormack 2011; Thorson 2000.

29 Van Kirk 1980: 125.

30 Van Kirk 1980: 126. From the mid-eighteenth century, a number of HBC officers took their wives and children to England, see Stephen 2006: 284-85.

31 Rollason Driscoll 2001: 93.

32 Rollason Driscoll 2001: 99-100. 
As the wife of a servant of the HBC, Agnes' brief relocation to London and the Orkney Islands marks her as unusual within fur-trade society; yet, it also usefully points to how, at times, Indigenous women's mobility was tied to the agency of mobile white men whose movement relied upon the global networks created out of resource economies such as the fur trade. While scholars of colonialism tend to agree that newcomers were commonly integrated into Indigenous communities through sex, marriage and kinship obligations, they tend to overlook the fact that Indigenous women's relationships with such men knitted them into global-trade networks, facilitating their movement across several colonial sites. ${ }^{33}$ The early New Zealand resource economy networks based around the timber trade, sealing and shore whaling operated in the same way, providing opportunities for Māori mobility, inclusive of the wives and daughters of Māori men or male newcomers. For instance, Irihāpeti Pātahi, a Kāi Tahu woman married by custom to the Australian-born and Otago-based shore whaler Edwin Palmer, travelled to Port Jackson (Sydney) with him in the 1830s, and thus into the economic heart of the trans-Tasman whaling trade. ${ }^{34}$

While marriage was at the centre of fur-trade society, Orcadians also drew families together into economic and social alliances through the bonds of marriage. ${ }^{35}$ Agnes, far removed from her own family, built familial ties that would sustain her for the remainder of her life. Upon her arrival in the Orkney Islands, she was brought into a tight kinship network; many of the families there were linked through marriage, and this pattern was replicated in New Zealand. The Harrolds arrived at Port Chalmers on the Bernicia in December 1848, one of the first group of colonists to the newly created colony of Otago. Also on board was James' mother, Margaret, his stepfather, Hugh Craigie, his brother Sinclair Harrold and half-brother Richard Craigie. Economics were the catalyst for the family's migration to southern New Zealand; previously tenants of a large estate, they had been pushed off the land by the owner who wished to consolidate the property into one large sheep farm. ${ }^{36}$

33 Ballantyne and Burton 2009.

34 See West 2009: 205-65.

35 See Harland 2013.

36 Stuart 1973: unpaginated. 
As the first Orkney family at the Taieri, the Harrolds actively sought to replicate Orkney social patterns and family life, for such practices invested place with meaning, activating important social and economic support networks. Not long after James and Agnes settled at Taieri, James' siblings followed them. The brothers set up a shipbuilding business and engaged in the coastal and river trade. ${ }^{37}$ The Harrold and Craigie families would eventually be joined by wider kin, including cousins, aunts and uncles, in a process of chain migration to Dunedin. Their cousin, William Harrold, migrated in 1861 from Victoria (Australia) on the advice of his relatives. James advertised in Orkney newspapers, encouraging islanders, especially young women of marriageable age, to seek out opportunities in Otago. ${ }^{38}$ In 1859 , the Yorston family arrived. Having originally intended to migrate to Red River in modern-day Manitoba, they changed their mind on receiving a letter from the Harrolds. ${ }^{39}$ In New Zealand, marriage tied the Orkney families together into a tight-knit community: Richard Craigie married into the Marwick family, who had arrived in Otago in 1857; ${ }^{40}$ James Knarston married Ann Marwick; and Julia Yorston married Walter Sinclair. ${ }^{41}$ These Orkney families were valuable employees, working as carpenters in the boatbuilding business and as labourers; they added value to the Harrold's ferry business by building stables and fences, as well as a 'two-storey residence, which ... was considered both stylish and large', in addition to an accommodation house. ${ }^{42}$ In 1857, the Otago Provincial Council assumed control of the building complex, leasing the tavern to Agnes and James. ${ }^{43}$

Orcadians were a reliable workforce and a vital economic support for the Harrolds. Their presence built the foundations of a small Orkney community at the lower Taieri, one tightly linked to the Presbyterian Church. ${ }^{44}$ Agnes and James lent support to the church, to local families and to the community. Charitable and generous, they cared for orphaned children without hesitation, notably the Harrison children, whose

\footnotetext{
37 Harper 1980: 94.

38 Harrold 1850.

39 Stuart 1981: 43, 51.

40 Stuart 1973: unpaginated; Otago Daily Times, 5 May 1978: 10.

41 Stuart 1981: 44, 46.

42 Obituary, Otago Witness, 2 June 1898: 55. James Harrold's bankruptcy file demonstrates the importance of his Orkney connections, his chief creditor being a relation, Hugh Marwick. Harrold 1864.

43 Parkes and Hislop 1980: 25.

44 Otago Witness, 21 August 1858: 1.
} 
parents died on the journey to Otago.$^{45}$ When they moved to Stewart Island in search of new economic opportunities in 1861, these familial relationships drew them back to the Taieri regularly-to mark important social occasions, attend funerals of family members and friends and to visit their son, James Joseph (1864-1911), who lived with relatives and attended the local school. ${ }^{46}$ Taieri remained an important touchstone and ongoing site of familial connection for the remainder of their lives - a place invested with deep social connections.

Agnes was an Indigenous woman; however, once she stepped ashore at Port Chalmers, she became a colonist. She benefited from the processes that facilitated the dispossession of Kāi Tahu, the local tribe. Between 1849 and 1861, Agnes bore witness to the flow of colonial goods, peoples and produce along the Taieri River, and profited from this mobility. She entered Kāi Tahu space, a location abundant with food that sustained Kāi Tahu communities who utilised long-established routes to access the riches of the Taieri Plain. Kāi Tahu knew Taieri Ferry as Takāihitau, one of many seasonal settlements conveniently located near the inland lakes and wetland that was utilised during the summer months as a base for resource gathering. Prior to systematic colonisation of the region in 1848, Kāi Tahu occupation at lower Taieri was concentrated along the banks of the river, underlining its significance as a travel route, economic and food resource, and site of seasonal and permanent settlement. ${ }^{47}$ While there is very little known about the history of these sites, their existence testifies to the mobile and seasonal nature of Kāi Tahu settlement, providing a map of Kāi Tahu mahika kai (resource gathering) trails and sites, as well as being indicators of use, occupation and the exercise of rights. ${ }^{48}$ Taieri was a dynamic space of seasonal mobility and settlement, and this pattern continued after formal British colonisation began.

Agnes' mobility contrasts with that practised by Jane Palmer. Jane lived at Maitapapa, the main settlement of the Taieri Native Reserve, situated at the point where the Taieri and Waipori rivers meet. The daughter of Irihāpeti Pātahi and Edwin Palmer, Jane and her older sister, Betsy, were born into the shore whaling industry that was prominent in southern regions during the 1830 s and 1840s. These connections are

45 Otago Witness, 27 December 1856: 3.

46 Anon. 1905: 894.

47 Taylor 1952: 181; Bray, Thomas and MacGill 1998: 8; Sutherland 1962: 9.

48 See Anderson 1998. 
most obviously reflected in the social and economic ties generated by that industry, especially through marriage. Betsy, for instance, married Richard Sizemore, a cooper at the Waikouaiti whaling station, who was the brother-in-law of the whaling magnate, Johnny Jones, who was owner of the station that Jane and Betsy's father was employed to manage. ${ }^{49}$ Like the Canadian fur trade, shore whaling stations had their own particular social hierarchies and marriage patterns, with Betsy's marriage to Sizemore marking Palmer as a man of rank and status in the shore whaling world. Jane, in contrast, married Robert Brown, also of mixed ancestry, and lived her entire married life at the reserve, where she and Robert raised eight children. Jane's kinship ties at Taieri were extensive, for Robert's sister lived at Maitapapa, as did Robert's mother, Mata Te Wharerimu, who was the senior woman there. Jane's father lived two kilometres away at the farming settlement of Otokia, but regularly stayed at her home. Jane's paternal uncle, William McLeur Palmer, lived at Maitapapa with his third wife, Ann Holmes, also a Kāi Tahu woman, and their growing family. ${ }^{50}$

Having grown up in a culturally diverse world, Agnes may have recognised many of the economic and social patterns in place at the reserve. From across the river, and in her role as hotel manager, she may have observed the mixed population in residence, which comprised Käi Tahu and exwhalers who had worked at several shore whaling stations along the Otago coastline. Among the residents were Australian-born brothers Edwin, William and Ned Palmer; uncle and nephew Robert and William Sherburd, also from Australia; William Low from Antigua; and John MacKenzie, a 'man of colour' from Jamaica. These men all married Kāi Tahu or mixed-descent women, and their residence on the reserve testifies to the importance of shore whaling stations in southern New Zealand as central sites for cross-cultural exchange. Intermarriage was an essential ingredient of the shore whaling industry; alliances were entered into by newcomers with the strong encouragement of Māori leaders, often with women of high status so as to gain the patronage of the local chief and access to land on which to establish a whaling operation. Interracial relationships were mutually beneficial. Newcomers were welcomed because the whaling industry fostered new economic conditions and trade relationships, bringing wealth to communities as well as to chiefly families. At the same time, marriage drew whalers into a network of

49 See Wanhalla 2005; Wanhalla 2008a.

50 The lives of these families are detailed in Wanhalla 2009. 
economic, political and social obligations. Like the Canadian fur trade, the relationships formed out of shore whaling were more than economic in nature. While they may have been contracted within the context of new trade conditions, what emerged out of the shore whaling era were permanent (rather than temporary) relationships, and the production of a mixed-descent population. Decades of intermarriage meant that crosscultural couples were not an unusual sight at Taieri, while the proximity of the river communities meant that colonists, Käi Tahu and cross-cultural couples encountered each other on a regular basis. Agnes and James would not have looked unlike their close neighbours across the river, although their ties to the church and to local industry no doubt gave them a social respectability rarely accorded to ex-whalers in Otago's nascent colonial society.

Surrounded by kin, both Kāi Tahu and Pākehā (European), Jane’s life was strongly tied to the lower Taieri, a native space she understood and no doubt experienced as 'a vast web of familial, political, and geographic relationships', constantly energised, animated and dynamically remade through a 'network of rivers and relations. ${ }^{51}$ Jane lived on a native reserve, an archetypal 'native space' generated by settler colonialism. Taieri's creation derived from the Otago Purchase of 1844, negotiated by the New Zealand Company, a private colonisation company. It was one of three areas excepted from purchase at the request of 21 Käi Tahu chiefs; they chose to retain Taieri because it was a vital route to the inland lakes and the wetland, rich in essential foods, including ducks, eels, weka and flounder. ${ }^{52}$ Added to this, the Taieri Plain contained the only large swamps south of the Waitaki River (the boundary of north Otago) that grew both harakeke (flax) and raupō (bulrush), the raw materials needed to make kete (baskets), apparel, rope, mats and fishing nets. ${ }^{53}$ Kāi Tahu also sought to retain access to their food cultivations and gardens located on the banks of the river. ${ }^{54}$ Apart from maintaining control over mahika kai (resource gathering sites), the area was of broader cultural significance, for it was the site of a traditional urupā (burial-place). ${ }^{55}$

51 Brooks 2008: xli.

52 Wilson 2002: 1.

53 Davis 1974: 58.

547 June 1844, Barnicoat Journal, MS-0440/01, Hocken Collections, Dunedin.

55 Clarke 1880. 
These resource sites marked out Käi Tahu pathways of mobility; however, this Indigenous geography would, over time, be disrupted by the creation of a native reserve on the northern bank of the river. Created out of the uneven power structures of colonialism and designed to fix people in one place, constraining, regulating and controlling their economic, social and cultural lives, native reserves altered Indigenous geographies. Although, as Canadian geographer Cole Harris noted, initially 'life came to be lived in, around, and well beyond these reserves', as settler colonialism expanded its reach, Indigenous movement became increasingly constrained, even in circumstances where mobility was not directly restricted by colonial authorities. ${ }^{56}$

Although they were residents of a native reserve, the Taieri Käi Tahu families were free to come and go, which they did for purposes of employment, hunting and fishing, and to partake in social, cultural and political events. There was no pass system. Unlike other colonial sites in which oversight on reservations and mission stations was a common part of the colonial experience, no resident missionary or colonial official closely managed the lives of Taieri's residents. Nevertheless, Jane and her kin lived in an environment in which the land was largely uneconomic, forcing them to rely on seasonal employment and to turn to the river and wetland as an essential source of sustenance. This reliance on the waterway system became increasingly fraught and difficult in the decades between the 1870s and 1920s, as local councils, river boards and central government sought to turn what they considered 'waste' land into productive farms. ${ }^{57}$ Eventually, the erosion of resources and the constraints of settler colonialism instituted new forms and patterns of Kài Tahu mobility, leading to the abandonment of the reserve as a site of permanent residence by the 1940s.

\section{$\star \star \star$}

Just like their male counterparts, Indigenous women's mobility followed imperial and colonial pathways that were not necessarily satisfying or productive of new relationships, connections or ties. Mobility could be an isolating experience, involving compulsion, violence and abandonment. Indigenous women's mobility could encompass great distances for reasons

56 Harris 2002: xxi.

57 See Wanhalla 2015. On the impact of swamp drainage on Indigenous communities in New Zealand, see Park 2013. 
ranging from the personal to the political, or follow much smaller and confined patterns along the routes and pathways of seasonal resource gathering, such as at the lower Taieri, where the river, lakes and wetland helped to sustain family life and cultural practices in the face of increasing pressures from local settlers, councils, river boards and central governments that sought to erode and erase Kāi Tahu resource rights. Jane Palmer's mobility was structured around this pattern of resource gathering for the purposes of maintaining connections to important cultural practices and, more pragmatically, to simply survive. ${ }^{58}$ New colonial conditions, namely life upon a native reserve, posed new challenges. At Taieri, systematic colonisation and the creation of a reserve space disrupted access to traditional seasonal settlements, which saw some localities abandoned and others activated as permanent sites of residence centred on agriculture. ${ }^{59}$ Rather than eradicating patterns of hunting or fishing, the reserve became one of a number of Indigenous geographies moved through and utilised by Kāi Tahu across the lower Taieri.

Jane's life, lived within the Taieri Native Reserve and its immediate vicinity, reinforces Alan Lester's claim that the 'majority of indigenous peoples tried to stay "grounded" in the midst of colonisation'. As Lester stressed, these were not static places, nor were their residents immobile; rather, the localities that 'indigenous people sought to cling onto simply became dynamic in new ways' ${ }^{60}$ As places, Taieri Ferry and the native reserve were constantly being moved through. In the mid-nineteenth century, they were busy with people, boats and goods, and were places where a lively, richly textured social life developed around work, harvesting, the church, picnics and weddings. Both communities participated in these events and practices. ${ }^{61}$ In its dynamic mixing of people, goods, accents and social practices, the lower Taieri was, to use Lester's phrase, 'a crossroads' constituted by a range of ongoing and ever-evolving connections and relationships. ${ }^{62}$ Tracing networks of kinship underscores the spatial dynamics of these localities. In general, the story of Taieri and its people is deeply tied to histories of dispossession, poverty and social marginalisation; however, by drawing attention to the coexisting

58 For further details about Kāi Tahu patterns of mobility as it was shaped by colonial conditions, see Waitangi Tribunal 1991.

59 For a discussion of the native reserve's geographies, and the impact of imposed colonial boundaries on mobility, see Wanhalla 2007.

60 Lester 2014: 53.

61 These shared geographies are outlined in Wanhalla 2015.

62 Lester 2013: 130. 
and overlapping colonial and Indigenous mobilities existing there, a more nuanced set of experiences are revealed. Taieri becomes a bustling and lively community of mobile men engaged in seasonal work; local and global networks of commerce and trade; and men, women and families who hunted and fished. When they gave evidence before commissions of inquiry, received the government gazette or Māori newspapers, wrote petitions and donated what little money they had to Te Kerēme (the Ngāi Tahu Claim Fund), these men, women and families were plugged into Kāi Tahu political networks and were active participants in colonial political discourse. ${ }^{63}$ Jane Palmer put her name to a petition: she sought to articulate her land and resource rights, and attended and participated in Kāi Tahu political meetings. ${ }^{64}$ Negating Caroline Daley's contention that Māori women's 'concerns [during the nineteenth century] were not national, let alone imperial', she was one of many Kāi Tahu women to engage in such practices. ${ }^{65}$ Indigenous women, including non-elites such as Jane, participated in empire, sometimes as its victims, but also as active and engaged participants who sought to make use of global networks and connections for their personal advantage, and on behalf of their family and community. Although, as Lester and Laidlaw noted, there were many Indigenous peoples who did not or could not engage with these imperial networks, their 'experience was no less shaped' by them and 'they were no less active participants in the new social assemblages attending colonization'. ${ }^{66}$ These dynamic histories and intersections are brought to life when mobility is integrated into the analysis of place.

For Jane, like many Indigenous women and their families, mobility was intimate and localised rather than expansive and transcolonial. For other Indigenous women, like Agnes, imperial pathways of mobility opened up different possibilities. In the first instance, imperial networks created opportunities for Indigenous-Indigenous encounters that could include profiting from the dispossession of others. ${ }^{67}$ Indigenous-Indigenous encounters, fashioned out of the pathways of imperial and colonial

63 Te Kerēme was a fighting fund established by Kāi Tahu leaders in the 1870s to gain restitution for historic injustices relating to Crown land purchases.

64 Although exposed to the English language from a young age, the documentary record associated with Jane and Robert demonstrates a preference for communicating with colonial officials in te reo Māori. While te reo was deployed for formal occasions, inclusive of hui (meetings) and official correspondence, the necessity of bartering with local colonists and employment on local farms meant the lingua franca of everyday communication was a mixture of English and Mãori.

65 Daley 2009: xxvi.

66 Lester and Laidlaw 2015: 8.

67 See Aikau 2010. 
networks, did not necessarily lead to natural alliances based on shared histories of injustice. In the case of Agnes and Jane, there is little evidence of any connection between them, even though their lives overlapped; there is no mention of Agnes in Käi Tahu sources, and there is nothing in the remaining documentary record associated with Agnes to suggest that she built any sustained relationships with the Taieri Kāi Tahu families. It appears that her ties to the Orcadian community sustained her subsequent relationship with Taieri, rather than any meaningful relationship with Maitapapa and its residents.

Mobility was important for Agnes, but in different ways; it presented her with economic, social and political opportunities that would have been unavailable to her in Canada. In 1893, when universal women's suffrage was achieved in New Zealand, Agnes gained political citizenship; she was also a landowner. ${ }^{68}$ In New Zealand, she was identified as Canadian. ${ }^{69}$ This identity and political status would not have been available to her had she remained in her birthplace; in Canada, her everyday life would have been structured and shaped by federal legislation - namely, the Indian Act 1876 that established patriarchal systems of descent, legal and political status, and property rights. ${ }^{70}$ Under the Act, male descent was entrenched as the primary mode of membership in a band, and an Indian was defined as any man of Indian blood, a child of an Indian man and any woman married to an Indian man. ${ }^{71}$ Any woman who married a non-status manthat is, someone not recognised under the Indian Act—or who engaged in intermarriage, was excluded from band membership and all the rights that came with having status, including living with her family and relations on a reserve. In short, marrying 'out' had serious material implications, including enforced mobility and disconnection from kinship networks. ${ }^{72}$

As decades of feminist scholarship have demonstrated, intermarriage meant that Indigenous women were integrated into and experienced imperialism and colonialism differently to their fathers, brothers and uncles. Intermarriage also shaped how some Indigenous women experienced mobility, as illustrated by the two women in this chapter whose lives momentarily overlapped,

68 Probate and Will of Agnes Harrold 1908, DAFG/D328/9066 Box 21/1790, Archives New Zealand.

69 The national census identifies only one Canadian woman living on Stewart Island in 1896, which I assume was Agnes Harrold. New Zealand Government 1896: 137.

70 Peters 1998: 672.

71 See Lawrence 2003.

72 See Wanhalla 2008b. 
before taking very different paths over the remainder of the nineteenth century. In New Zealand, intermarriage did not limit Agnes from achieving political freedom or prevent her from assuming a Canadian identity, nor did it restrict her from gaining a measure of economic independence, symbolised by her wide-ranging mobility. However, intermarriage did disconnect Agnes from her family in Canada, forcing her to build new kinship ties with Taieri's Orcadian community, far from Manitoba. In contrast, intermarriage gave Jane a wide network of relations that stretched into southern New Zealand and across to Sydney. As she entered adulthood and raised a family, Jane's cultural, economic and social world was increasingly constrained by colonial development and 'progress' in which Kāi Tahu patterns of seasonal mobility were neither valued, nor acknowledged; yet, she remained highly mobile. Kin-based geographies, which could stretch across a vast terrain, are crucial methodological tools for making visible the various ways in which Indigenous women's mobilities were activated and shaped by imperial and colonial power relations, including how colonisation facilitated opportunities for women to be mobile in new ways. ${ }^{73}$

\section{References}

Aikau, Hokulani K. 2010, 'Indigeneity in the diaspora: The case of native Hawaiians at Iosepha, Utah', American Quarterly 62(3): 477500. doi.org/10.1353/aq.2010.0014

Anderson, Atholl 1998, The Welcome of Strangers: An Ethnohistory of Southern Maori, AD 1650-1850, Otago University Press, Dunedin.

Anderson, Clare 2011, 'Writing Indigenous women's lives in the Bay of Bengal: Cultures of empire in the Andaman Islands, 1789-1906', Journal of Social History 45(2): 480-96. doi.org/10.1093/jsh/shr054

Anderson, Clare 2012, Subaltern Lives: Biographies of Colonialism in the Indian Ocean World, 1790-1920, Cambridge University Press, Cambridge. doi.org/10.1017/CBO9781139057554

Anon. 1905, 'Harrold, James Joseph', in The Cyclopedia of New Zealand, volume 4, Otago and Southland Provincial Districts, Cyclopedia Company Ltd, Christchurch.

73 On the the opportunities and contraints colonisation offered Indigenous women, see Haskins 2009. 
Ballantyne, Tony 2011, 'On place, space and mobility in nineteenthcentury New Zealand', New Zealand Journal of History 45(1): 50-70.

Ballantyne, Tony 2012, Webs of Empire: Locating New Zealand's Colonial Past, Bridget Williams Books, Wellington. doi.org/10.7810/ 9781927131435

Ballantyne, Tony and Antoinette Burton (eds) 2009, Moving Subjects: Gender, Mobility and Intimacy in an Age of Global Empire, University of Illinois Press, Urbana.

Banivanua Mar, Tracey 2013, 'Imperial literacy and Indigenous rights: Tracing transoceanic circuits of a modern discourse', Aboriginal History 37: $1-28$.

Banivanua Mar, Tracey 2015, 'Shadowing imperial networks: Indigenous mobility and Australia's Pacific past', Australian Historical Studies 46(3): 340-55.

Barman, Jean and Bruce McIntyre Watson 2006, Leaving Paradise: Indigenous Hawaiians in the Pacific Northwest, 1787-1898, University of Hawai'i Press, Honolulu.

Beardy, Flora and Robert Coutts (eds) 1996, Voices from Hudson Bay: Cree Stories from York Factory, McGill-Queens University Press, Montreal.

Beaumont, Raymond M. 1984, 'The Grieves of Oxford House', unpublished manuscript, Hudson's Bay Company Archives (HBCA), Archives of Manitoba, Winnipeg.

Bray, Sharron, Graeme Thomas and Victor MacGill 1998, Under the Eye of the Saddle Hill Taniwha: Maori Place Names and Legends as Viewed from Saddle Hill, Extending from Green Island South to Taieri Mouth and across to Maungatua, then North to the Silverpeaks, Ngā Tutukitanga o Taieri, Mosgiel.

Brooks, Lisa 2008, The Common Pot: The Recovery of Native Space in the Northeast, University of Minnesota Press, Minneapolis.

Burley, Edith I. 1997, Servants of the Honourable Company: Work, Discipline, and Conflict in the Hudson's Bay Company, 1770-1879, Oxford University Press, Oxford. 
Burton, Antoinette 2012, 'Travelling criticism? On the dynamic histories of Indigenous mobility', Cultural and Social History 9(4): 491-96. doi.org/10.2752/147800412X13434063754409

Carey, Jane and Jane Lydon (eds) 2014, Indigenous Networks: Mobility, Connections and Exchange, Routledge, London.

Clarke jnr, George 1880 (7 April), Letter to Commissioner of Land Purchases, Appendix 33 in Minutes of Evidence, Smith-Nairn Commission, MA 67/8, Archives New Zealand (ANZ).

Daley, Caroline (ed.) 2009, Women and Empire, 1750-1930. Primary Sources of Gender and Anglo-Imperialism, volume 2, New Zealand, Routledge, London.

Daniels, Stephen and Catherine Nash 2004, 'Lifepaths: Geography and biography', Historical Geography 30: 449-58. doi.org/10.1016/S03057488(03)00043-4

Davis, G.F. 1974, 'Old identities and new iniquities: The Taieri Plain in Otago Province 1770-1870', MA thesis, University of Otago.

Elbourne, Elizabeth 2005, 'Indigenous peoples and imperial networks in the early nineteenth century: The politics of knowledge', in Rediscovering the British World, Philip Buckner and R. Douglas Francis (eds), University of Calgary Press, Calgary: 59-86.

Harland, Jill 2013, 'The Orcadian odyssey: The migration of Orkney Islanders to New Zealand, 1848-1914 with particular reference to the South Island', $\mathrm{PhD}$ thesis, University of Otago.

Harper, Barbara 1980, Petticoat Pioneers: South Island Women of the Colonial Era, book 3, Reed, Wellington.

Harris, Cole 2002, Making Native Space: Colonialism, Resistance, and Reserves in British Columbia, University of British Columbia Press, Vancouver.

Harrold, James 1850 (10 January), Letter to Superintendent, Otago Provincial Council, AAAC/707/D500 Box 132/a/11, ANZ.

Harrold, James 1864, Debtor's File, DAAC/D256/20364 Box 620/181, ANZ. 
Haskins, Victoria 2009, 'From the centre to the city: Modernity, mobility and mixed-descent Aboriginal domestic workers from Central Australia', Women's History Review 18(1): 155-75. doi.org/ 10.1080/09612020802608108

Hoxie, Frederick E. 2014, 'Denouncing America's destiny: Sarah Winnemucca's assault on US expansion', in Critical Perspectives on Colonialism: Writing the Empire from Below, Fiona Paisley and Kirsty Reid (eds), Routledge, London: 27-45.

Lai, Paul and Lindsey Claire Smith 2010, 'Introduction', American Quarterly 62(3): 407-36.

Laidlaw, Zoe 2014, 'Indigenous interlocutors: Networks of imperial protest and humanitarianism in the mid-nineteenth century', in Indigenous Networks: Mobility, Connections and Exchange, Jane Carey and Jane Lydon (eds), Routledge, London: 114-39.

Lawrence, Bonita 2003, 'Gender, race, and the regulation of native identity in Canada and the United States: An overview', Hypatia: A Journal of Feminist Philosophy 18(2): 3-31.

Legge, Carol 1991, 'Ata-Hoe', in The Book of New Zealand Women: Ko Kui Ma Te Kaupapa, Charlotte Macdonald, Merimeri Penfold and Bridget Williams (eds), Bridget Williams Books, Wellington: 23-25.

Lester, Alan 2013, 'Spatial concepts and the historical geographies of British colonialism', in Writing Imperial Histories, Andrew S. Thompson (ed.), Manchester University Press, Manchester: 118-42.

Lester, Alan 2014, 'Indigenous engagements with humanitarian governance: The Port Phillip Protectorate of Aborigines and "humanitarian space"', in Indigenous Networks: Mobility, Connections and Exchange, Jane Carey and Jane Lydon (eds), Routledge, London: $50-74$.

Lester, Alan and Zoe Laidlaw 2015, 'Indigenous sites and mobilities: Connected struggles in the long nineteenth century', in Indigenous Communities and Settler Colonialism: Land Holding, Loss and Survival in an Interconnected World, Alan Lester and Zoe Laidlaw (eds), Palgrave Macmillan, London: 1-23. 
McCormack, Patricia A. 2011, 'Lost women: Natives wives in Orkney and Lewis', in Recollecting: Lives of Aboriginal Women of the Canadian Northwest and Borderlands, Sarah Carter and Patricia A. McCormack (eds), Athabasca University Press, Edmonton: 61-88.

Medak-Saltzman, Danika 2010, 'Transnational Indigenous exchange: Rethinking global interactions of Indigenous peoples at the 1904 St. Louis exposition', American Quarterly 62(3): 591-615.

Morgan, Cecilia 2014, “'Write me. Write me”: Native and metis letterwriting across the British Empire, 1800-1870', in Critical Perspectives on Colonialism: Writing the Empire from Below, Fiona Paisley and Kirsty Reid (eds), Routledge, London: 141-56.

New Zealand Government 1896, Results of a Census of the Colony of New Zealand Taken for the Night of the 12th April 1896, Government Printer, Wellington.

O'Brien, Patricia 2006, The Pacific Muse: Exotic Femininity and the Colonial Pacific, University of Washington Press, Seattle.

O’Brien, Patricia 2014, 'Ta' isi O.F. Nelson and Sir Maui Pomare: Samoans and Maori reunited', Journal of Pacific History 49(1): 26-49. doi.org/ $10.1080 / 00223344.2013 .878288$

O’Malley, Vincent 2015, Haerenga: Early Mãori Journeys Across the Globe, Bridget Williams Books, Wellington.

Park, Geoff 2013, “'Swamps which might doubtless easily be drained": Swamp drainage and its impact on the Indigenous', in Making a New Land: Environmental Histories of New Zealand, Eric Pawson and Tom Brooking (eds), Otago University Press, Dunedin: 174-92.

Parkes, Win and Kath Hislop 1980, Taieri Mouth and its Surrounding Districts, Otago Heritage Books, Dunedin.

Paterson, Lachy 2013, “"The similarity of hue constituted no special bond of intimacy between them": Close encounters of the Indigenous kind', Journal of New Zealand Studies (14): 19-40.

Perry, Adele 2015, Colonial Relations: The Douglas-Connolly Family and the Nineteenth Century Imperial World, Cambridge University Press, Cambridge. doi.org/10.1017/CBO9781139794701 
Peters, Evelyn J. 1998, 'Subversive spaces: First nations women and the city', Society and Space 16(6): 665-85.

Rollason Driscoll, Heather 2001, "A most important chain of connection”: Marriage in the Hudson's Bay Company', in From Rupert's Land to Canada, Theodore Binnema, Gerhard J. Ens and R.C. MacLeod (eds), University of Alberta Press, Edmonton: 81-110.

Russell, Lynette 2012, Roving Mariners: Australian Aboriginal Whalers and Sealers in the Southern Oceans, 1790-1870, SUNY Press, New York.

Ships' Logs 1847, Prince Rupert (V), C.1/952 and C.1/954, HBCA, Archives of Manitoba, Winnipeg.

St-Onge, Nicole, Carolyn Podruchny and Brenda Macdougall (eds) 2012, Contours of a People: Metis Family, Mobility, and History, University of Oklahoma Press, Norman.

Stephen, Scott P. 2006, 'Masters and servants: The Hudson's Bay Company and its personnel, 1668-1782', PhD thesis, University of Manitoba.

Stuart, R.J. 1981, Henley, Taieri Ferry and Otokia: A Schools and Districts History, Henley, Taieri Ferry and Otokia School Jubilee Committee, Outram.

Stuart, R.J. 1973, Craigie-lea: Written for the 125th Anniversary of the Emigration of the Craigies, of Brugh, Rousay, Orkney, to New Zealand, R. Stuart, Dunedin.

Sutherland, Gwen 1962, Coast, Road and River: The Story of Taieri Mouth, Taieri Beach, Glenledi and Akatore, Clutha Leader, Balclutha.

Taylor, W.A. 1952, Lore and History of the South Island Maori, Bascands Limited, Christchurch.

Thorson, Bruce 2000 (November/December), 'The bay connection: Orkney Islanders discover their metis heritage', Canadian Geographic 120(7): 98-104.

Van Kirk, Sylvia 1980, Many Tender Ties: Women in Fur-Trade Society, 1670-1870, University of Oklahoma Press, Norman.

Waitangi Tribunal 1991, The Ngai Tahu Report, Waitangi Tribunal, Wellington. 
Wanhalla, Angela 2005, 'Transgressing boundaries: The mixed descent families of Maitapapa, Taieri, 1840-1940', PhD thesis, University of Canterbury.

Wanhalla, Angela 2007, "My piece of land at Taieri”: Boundary formation and contestation at the Taieri Native Reserve, 1844-1868', New Zealand Journal of History 40(1): 44-60.

Wanhalla, Angela 2008a, “'One white man I like very much”: Intermarriage and the cultural encounter in southern New Zealand, 1829-1850', Journal of Women's History 20(2):34-56. doi.org/10.1353/jowh.0.0013

Wanhalla, Angela 2008b, 'Women "living across the line": Intermarriage on the Canadian prairies and southern New Zealand, 1870-1900', Ethnohistory 55(1): 29-49. doi.org/10.1215/00141801-2007-045

Wanhalla, Angela 2009, In/visible Sight: The Mixed Descent Families of Southern New Zealand, Bridget Williams Books, Wellington. doi.org/10.7810/9781877242434

Wanhalla, Angela 2015, 'Living on the rivers' edge at the Taieri Native Reserve', in Indigenous Communities and Settler Colonialism: Land Holding, Loss and Survival in an Interconnected World, Alan Lester and Zoe Laidlaw (eds), Palgrave Macmillan, London: 138-57.

Warrior 2005, The People and the Word: Reading Native Non-Fiction, University of Minnesota Press, Minneapolis.

Weaver, Jace 2014, The Red Atlantic: American Indigenes and the Making of the Modern World, 1000-1927, University of North Carolina Press, Chapel Hill.

West, Jonathan 2009, 'An environmental history of the Otago peninsula: Dialectics of ecological and cultural change from first settlement to 1900', PhD thesis, University of Otago.

Whyte, Donald 1995, A Dictionary of Scottish Emigrants to Canada Before Confederation, volume 2, Ontario Genealogical Society, Toronto.

Wilson, Catherine 2002, 'Tatawai, Kai Tahu and the claim', BA (Hons) long research essay, University of Otago. 
This text is taken from Indigenous Mobilities: Across and Beyond the Antipodes, edited by Rachel Standfield, published 2018 by ANU Press, The Australian National University, Canberra, Australia.

doi.org/10.22459/IM.06.2018.09 